\title{
Empowering the Frontline Police Officers to Cope with Police Social Service Role Strain in China
}

\author{
Xiaohai Wang*
}

\author{
College of Criminal Investigation, Southwest University of Political Science and Law, No.301, Baosheng \\ Avenue, Huixing Street, Yubei District, Chongqing 401120, China
}

\begin{abstract}
Provision of social service is one of the most significant roles of the police. A review of the related literature in policing seems to reveal that empowerment holds significance for frontline officers who are largely responsible for social service delivery. This study examines the possible relationships between police social service structural empowerment (PSSSE), police social service psychological empowerment (PSSPE) and police social service role strain (PSSRS) among frontline police officers in China. This study adopts a two-phase (quantitative and qualitative approaches) sequential explanatory design. In the first phase, a questionnaire is used to collect data from a sample of two hundred frontline community patrol officers in Shenzhen Public Security Bureau, China. After conducting the quantitative analysis, the author uses in-depth interviews to explore the nature of PSSRS, PSSSE, PSSPE from twelve selected interviewees' insights. According to the results of the survey and in-depth interviews, the participants report a comparatively high level of PSSRS and low levels of PSSSE and PSSPE. It has been found that there are significantly negative correlations between PSSSE, PSSPE and PSSRS in the Chinese police organization. The Chinese police force is suggested to provide effective interventions for individual experience of psychological empowerment and reorganize the current paramilitary-bureaucratic model by changing the management practices for structural empowerment in response to the PSSRS among frontline police officers.
\end{abstract}

Keywords: Social service, role strain, empowerment, police, China.

\section{INTRODUCTION}

Law enforcement and order maintenance are generally viewed as the two main duties of the police force. In addition to these two duties, the police are also frequently requested by the public to deliver social services (Reid, 2001; Cox, 1996; Magenau \& Hunt, 1996). As one of the law enforcement statutory service teams, the police are expected to provide immediate aid and care to the public along with compulsory, regulatory, control, and defense practices. Provision of social services is one of the most significant roles of the contemporary police. Studies have shown that the police spend most of their time providing social services to the public (Greene \& Klockars, 1991). Based on the 2007 Law Enforcement Management and Administrative Statistics (LEMAS) report in the United States, the primary function of one-fifth of the police agencies was search and rescue. Specifically, nearly 60 percent of police officers undertook animal control tasks, nearly one-sixth of police agencies were responsible for providing emergency and medical services and carry out civil defense functions, and about one-tenth of police agencies provided fire prevention services (Hickman \& Reaves, 2001).

*Address correspondence to these authors at the College of Criminal Investigation, Southwest University of Political Science and Law No.301, Baosheng Avenue, Huixing Street, Yubei District, Chongqing 401120, China; Tel: (86)13883288692; E-mail: policewangxiaohai@hotmail.com
Since 1979, Chinese policing has undergone tremendous changes in response to economic reform and crime problems. To meet these legal and social challenges, the Chinese police have begun to establish a path to institutional police reform based on the rhetoric of professionalization (including modernization, formalization, and legalization). First, the police organization formalized itself along functional lines to increase organizational efficiency. Second, police legislation and the conception of rule of laws have been gradually developed. Third, the 110 emergency line (equivalent to the American 911 or British 999) and police patrol have been widely established in cities (Wong, 2009). These two measures-police patrol and the 110 emergency line - have transformed Chinese policing from "passive" to "proactive" (Wong, 2009). Pursuing a faster response time and more responsiveness to public calls for police services, the 110 emergency line is combined with the police patrol and has been established in every city in China (Dai, 2008). The frontline police officers at the local police stations are mobilized by telephone solicitation and radio dispatches from the 110 command center to cater to the community residents' requests and needs.

In 1996 the Ministry of Public Security (MPS) enacted the policy of 'four have's and four should's' (FHFS), which delineated duties for the frontline police officers. According to the policy of FHFS, the police 'should handle any crime problems you have', 'should help with any difficulties you have', 'should save you 
from any dangers you have', and 'should meet any needs you have'. As a result, the social service workload of frontline police officers multiplied since launching the policy of FHFS. According to Wang \& Wong (2012), the Chinese police force received 11.35 million 110 emergency calls for social service nationwide in 2010. What was worse, some citizens mishandled the 110 emergency call service by calling to ask the police to send fresh flowers and buying breakfasts (Zhong, 2009). The FHFS, which pledges response, help, and rescue for all requests, has caused many problems for frontline police officers. The emergence of the emergency line and the FHFS policy can be considered a drain on police resources. Many studies conducted by police scholars have described the job-related stress experienced by police officers in China (Zhou, 2005; Sun, 2007). A number of studies have taken a quantitative approach to investigate the job strain of Chinese police officers. Jiang, Xu, and Deng (2005) investigated a sample of 252 police officers from 6 provinces in China and discovered that strain associated with police work is positively associated inadequate support for the police force. All these studies demonstrated that Chinese police officers perceive a comparative high level of police social service role strain (PSSRS).

According to the role scarcity perspective to human energy proposed by Goode (1960) and Marks (1977), institutions (e.g. the police force) are role systems, and that individual's total role expectations are overdemanding because of limits on personal resources such as time, energy and attention that can be devoted to fulfilling theses expectations. Therefore, overdemanding role expectations produce a strong tendency toward role strain. This role scarcity perspective provides a useful theoretical base to conceptualize the experience of frontline police officers who provide over-demanding social service to the community.

The role theory has been widely applied in the psychology of adjustment. The key term 'role strain' is coined by Goode (1960, p.493) and defined as 'the difficulty of fulfilling role demands'. Role strain refers to the experience of discomfort, pressure, tension or frustration that may arise as people function in their organization. Since specific expectations are attached to the social service role that the police cannot fulfill, by definition he/she experiences role strain. As used in this study, police social service role strain (PSSRS) is defined as the distressful psychological experiences that are associated with the police social service role.
PSSRS is a continuous variable that can range from very low to very high.

Role strain theory may have yet provided appropriate and sufficient explanations of coping. Another theory, empowerment theory (Conger\& Kanungo, 1988; Thomas\& Velthouse, 1990; Spreitzer, 1995a, 1995b, 1996, 1997), seems ideally suited to this task, because it explicitly proposes coping variables that target the role strain. Coping responses are the actual behaviors and cognitions that individuals employ in their attempts to deal with role strain. Coping responses may serve the protective function of managing the emotional distress (Pearlin\& Schooler, 1978). In this study, coping is defined as structural and psychological responses to manage particular role strain that is exceeding the resources of the frontline police officers.

Kanter (1979; 1993) argues that attitudes and behaviors are reactions to an individual's position within an organization. The organization tends to benefit from the organizational effectiveness under the condition that employees perceive the empowerment in structured situations (Laschinger, 1996). The structures within organizations that Kanter believes to be vital for employee empowerment are having access to opportunity, resources, information, support, formal and informal power. When there are insufficient social structures in the organization, employees tend to feel that their contributions to the organizational objectives are not adequately valued and respected and that indispensable resources are unavailable for performing their roles. This study, building on the basis of Kanter's $(1979 ; 1993)$ structural empowerment theory, defines police social service structural empowerment (PSSSE) as the frontline police officers' perception of empowerment structures concerned with their social service work, including the access to opportunity, information, support, resources, informal and formal power. The meaning of each research concept related to structural empowerment is described as follows (See Table 1):

Conger and Kanungo (1988, p. 474) defined psychological empowerment as the process of 'enhancing feelings of self-efficacy...' among employees through removal of powerlessness conditions and provision of efficacy information. 'Selfefficacy refers to a belief in one's capabilities to mobilize the motivation, cognitive sources, and courses of action needed to meet given situational demands' (Bandura, 1990, p. 472). Thomas and Velthouse (1990) 
Table 1: Definition of Police Social Service Structural Empowerment Construct

\begin{tabular}{|c|c|}
\hline $\begin{array}{c}\text { Components of Police Social Service } \\
\text { Structural Empowerment (PSSSE) }\end{array}$ & Definition \\
\hline \hline Access to information & $\begin{array}{r}\text { Constant access to information regarding organizational decisions and policy changes that } \\
\text { may have an impact on frontline police officers' social service work. }\end{array}$ \\
\hline Access to support & $\begin{array}{r}\text { Encompassing the problem-solving guidance and positive response received from superiors } \\
\text { and peers to improve frontline police officers social service work effectiveness. }\end{array}$ \\
\hline Access to resources & $\begin{array}{r}\text { The ability of frontline police officers to exert influence outward and access to the supplies, } \\
\text { time, and equipment required to achieve social service work objectives. }\end{array}$ \\
\hline Access to opportunity & $\begin{array}{r}\text { Frontline police officers' own role expectations and potential for advancement that allows for } \\
\text { mobility and professional growth inside the police organization. }\end{array}$ \\
\hline Formal power & $\begin{array}{r}\text { Social service work characteristics (flexibility, adaptability, creativity, visibility associated with } \\
\text { social service work) that lead to job recognition and achievement of organizational objectives } \\
\text { in the police organization. }\end{array}$ \\
\hline Informal power & $\begin{array}{r}\text { Development of informal and effective social connection and communication and information } \\
\text { channels within the police organization or multi-agency. }\end{array}$ \\
\hline
\end{tabular}

further developed the pioneered concept of empowerment by conceptualizing empowerment as the construct of four cognitions (meaning, competence, choice, and effect) that are interrelated for the determination of employee empowerment. The psychological empowerment construct proposed by Thomas and Velthouse has been extensively recognized due to its multi-aspect analysis on an individual's cognitions (Spreitzer, Kizilos \& Nason, 1997). Building on conceptions of Thomas and Velthouse (1990), Spreitzer (1995a) defines empowerment as a psychological state illustrated in four cognitions: meaning, competence, selfdetermination, and impact. Self-determination and impact parallels 'choice' and 'effect' in the study by Thomas and Velthouse (1990). The psychological empowerment can be considered to be a continuous variable (greater or lesser empowerment in the organization). Spreitzer (1995a) found in her study that each component of empowerment contributes to an overall construct of psychological empowerment and all these four components manifest a positive orientation of a work role. This positive orientation of one's work role reflects an individual's expectations for shaping his/her work context or role. This study, building on the basis of Spretizer's (1995a;1995b;1996;1997) psychological empowerment theory, defines police social service psychological empowerment (PSSPE) as a construct of social service work motivation illustrated in a constellation of four dimensions: meaning, competence, self-determination, and impact. The meaning of each dimension is described as follows (See Table 2):

The empowerment model of Laschinger, Finegan and Shamian (2001) has provided an integrated conceptual model for investigating the role of structural and psychological empowerment in alleviating PSSRS in the police organization. With the aim of contributing to the policing study in relation to PSSRS, the current study attempts to provide evidence from the examination of PSSSE and PSSPE among Chinese frontline police officers. This study attempts to propose and answer three research questions as follows:

1) What is the degree of PSSRS among frontline police officers in China?

Table 2: Definition of Police Social Service Psychological Empowerment Construct

\begin{tabular}{|c|c|}
\hline $\begin{array}{c}\text { Components of Police Social Service Psychological } \\
\text { Empowerment (PSSPE) }\end{array}$ & Definition \\
\hline Meaning & $\begin{array}{c}\text { The value of the social service work objective as judged by the frontline police } \\
\text { officers }\end{array}$ \\
\hline Competence & $\begin{array}{l}\text { The frontline police officer's confidence in ones' social service work } \\
\text { performance abilities }\end{array}$ \\
\hline Self-determination & $\begin{array}{l}\text { The frontline police officer's sense of having freedom or autonomy to choose } \\
\text { how to do social service work. }\end{array}$ \\
\hline Impact & $\begin{array}{l}\text { The extent to which the frontline police officer can have influence on } \\
\text { organizational outcome regarding social service work. }\end{array}$ \\
\hline
\end{tabular}


2) How to cope with PSSRS of frontline police officers in China?

The following 12 hypotheses are proposed for this study:

1) Hypothesis 1: PSSSE is associated with PSSRS, with frontline police officers who access to more structural empowerment reporting less PSSRS.

2) Hypothesis 2: Access to opportunity is negatively associated with PSSRS among frontline police officers.

3) Hypothesis 3: Access to information is negatively associated with PSSRS among frontline police officers.

4) Hypothesis 4: Access to support is negatively associated with PSSRS among frontline police officers.

5) Hypothesis 5: Access to resources is negatively associated with PSSRS among frontline police officers.

6) Hypothesis 6: Access to formal power is negatively associated with PSSRS among frontline police officers.

7) Hypothesis 7: Access to informal power is negatively associated with PSSRS among frontline police officers.

8) Hypothesis 8: PSSPE is associated with PSSRS, with frontline police officers who access to more psychological empowerment reporting less PSSRS.

9) Hypothesis 9: A sense of meaning is negatively associated with PSSRS among frontline police officers.

10) Hypothesis 10: A sense of competence is negatively associated with PSSRS among frontline police officers.

11) Hypothesis 11: A sense of self-determination is negatively associated with PSSRS among frontline police officers.

12) Hypothesis 12: A sense of impact is negatively associated with PSSRS among frontline police officers.

\section{RESEARCH METHODS}

\section{Participants}

This study is limited to urban police stations of Shenzhen Public Security Bureau (SZPSB) in Shenzhen, China. The sample for this study includes 200 Community Patrol Officers (CPO) within police stations: 120 CPOs from the Shenzhen Economic Zone (SEZ) and 80 CPOs from the Non-Shenzhen Economic Zone (NSEZ). All participants are volunteers and are included based on their willingness to participate. Inclusion criteria includes employment as a CPO for at least 1 year, being between the ages of 20 and 55 years, and able to read and write Chinese language. A wide age range is selected to allow for adequate variability in the sample. The sample also includes all ranks and specific duty assignments in the police station, to encompass CPOs performing social service duties. The work of these participants mainly consists of patrol, community participation, and offering emergent police service to civilians. All the participants are confined to tasks that are highly related to the social service.

\section{Instrumentation}

This study has adopted the structured questionnaire survey for data collection. There are four measuring instruments in the questionnaire of this study.

\section{1) Police Social Service Role Strain Scale}

The scale measuring police social service role strain (PSSRS) in the current survey is comprised of six items and has be adopted with revisions from the Work Stress Measure (WSM) originally developed by Cullen, Link, Wolf and Frank (1985). The six items included in the current study are rated on a seven-point scale from 1 (very strongly disagree) to 7 (very strongly agree). Assessing how anxious or pressured police officers felt while on duty, the WSM has a strong reliability coefficient of .78 (Cullen, Link, Wolf\& Frank, 1985).

\section{2) Police Social Service Structural Empowerment Scale}

Structural empowerment is measured by using the Police Social Service Structural Empowerment Scale. Adapted from the original Conditions of Work Effectiveness Questionnaire-II (CWEQ-II) (Laschinger et al., 2001), the Police Social Service Structural Empowerment Scale includes 19 items that measure all of Kanter's (1979; 1993) six empowerment structures. Particularly, a global empowerment scale 
(two items) is used for validating. All items are rated on a 5-point Likert scale. The structure of these empowerment measures has recently been validated by Laschinger et al. (2001), creating a total empowerment score by adding six subscales of the CWEQ-II with a score range from 6 to 30. Based on previous studies, Cronbach's alpha reliabilities range from 0.79 to 0.82 (Laschinger \& Havens, 1996; Baguley, 1999).

\section{3) Police Social Service Psychological Empowerment Scale}

Police Social Service Psychological Empowerment Scale is developed by adapting from Spreitzer's (1995a) Psychological Empowerment Instrument (PEI) to measure individual opinions in relation to psychological empowerment among participants. Using a seven-point Likert scale with scores ranging from 1 (strongly disagree) to 7 (strongly agree), Spreitzer employs three items for measuring each dimension (total of 12 items). The total score of the psychological empowerment scale has a possible range from 12 to 84. Based on the review of experts on police study and the feedback from respondents in the pilot study, three items in the original PEI are deleted for the experts and respondents pointed out that these three items in the Chinese translation are almost identical with others in the same subscale. In this study, the total number of items in the modified Police Social Service Psychological Empowerment Scale is 9.

\section{4) Demographic Data}

A demographic sheet is designed to collect data regarding the respondents' characteristics and career state. Data included age, sex, education, police work experience, job location. Demographic data are used only to describe the sample.

\section{Procedures}

This study adopts a two-phase (quantitative and qualitative approaches) sequential explanatory design. The first phase of the mixed research uses a questionnaire to collect data from a sample of frontline CPOs. Considering the unavailable sampling frame, economic feasibility and accessibility to the target population, I non-randomly selected a sample of CPOs for this study. Two hundred questionnaires were distributed among the CPOs of eight police stations. One hundred and eighty questionnaires were filled and returned appropriately representing a 90 percent response rate. After conducting the quantitative analysis, in-depth interviews are used to explore the nature of PSSRS, PSSSE and PSSPE from the insights of 12 selected CPOs. The interviews are conducted using the phenomenological method to deduce the participants' perceptions of the police social service role stain. The scripts are transcribed and grouped into themes. Each theme mentioned by the participants is presented along with supporting data. The interviewees' responses from the qualitative study are also chosen to compare and contrast with the statistical findings. The data collected from the interviews is used to supplement the findings of quantitative study.

After permission to conduct the study had been obtained from each selected police station, a schedule of times of entry into these police stations for survey and interview was established. By using the Shenzhen Telephone Directories (Shenzhen Yellow Pages), the researcher prepared a list of the names, telephone numbers, and addresses of these selected police stations. Initially, the researcher contacted these leaders of police stations by telephone and scheduled a date to attend the roll-calls within police stations. Those leaders cooperated with the researcher's requests, providing the researcher with time at the beginning of the roll-calls to recruit volunteers for this study.

The survey was administered under the normal work conditions of CPOs (on the job location). The researcher attended the roll-calls (before day, swing or graveyard shifts) of the CPT in the police station in order to obtain a good sample that was representative of the CPOs. In each of these selected police stations, the leaders and police officers were informed about the intent of the present study and the strict confidentiality of the data collection. In addition, volunteer participation and the anonymity of the survey results were emphasized. The frontline CPOs were invited to involve in the survey and were given the selfadministered questionnaires at the beginning of their shift and requested to return them to the researcher at the end. Those CPOs who were willing to participate were given packets of questionnaires and return envelopes. Each bundle of questionnaires included two pages of instructions describing the purposes of the present study, directions for completion and six pages of the survey and demographic information. In the envelope the participants were able to confidentially return the sealed envelope with questionnaire to the researcher upon completion. Those who did not want to take part could simply return the blank questionnaire to me in the envelope. 
After conducting the survey, potential participants that were interested in the in-depth interview were requested to provide the researcher with a contact number for follow-up. The researcher then contacted these potential interviewees via phone calls. After several phone calls, all twelve CPOs agreed to be interviewed, and the exact dates and times for interview were arranged. All interview locations and times were arranged at the convenience of the participants. As a result, all interviews were conducted in the researcher's temporary accommodation in Shenzhen. Interviews were conducted in a semistructured approach, enabling me to probe, explore, and to gain a deep understanding of predetermined inquiry areas (Patton, 1990). In the interview, strategies of elicitation and clarification were applied to encourage interviewees to talk freely about their social service work experiences in the police stations, interjecting as necessary for exploration regarding the centered topics. To make interviewees effectively free to express their perspectives and personal experiences, Mandarin was the main language used in the interviews. During the interviews, notes were taken instead to stimulate the interviewees' flow of data. In some cases verbatim notes were taken, but many times the responses were paraphrased and repeated to the respondent to assure accurate responses. Once the interviews were completed, interviews were then transcribed and read for analysis and interpretation.

\section{DATA ANALYSIS}

The quantitative analysis of data was conducted on the basis of the research hypotheses proposed for this study. The data collected from the coded questionnaire were analyzed by using the Statistical Package for Social Sciences $15^{\text {th }}$ version (SPSS) using descriptive, correlation techniques. Descriptive statistics were used to describe the general characteristics of the data and provided summaries about measures and the demographical and professional characteristics of the sample. To identify the level of PSSRS, PSSSE and PSSPE among the participants, data were analyzed using parametric statistics. The $t$ test was conducted to assess whether there are significant differences in PSSRS, PSSSE and PSSPE due to personal characteristics. Bivariate correlation analyses investigated the possible theoretical relationships between PSSRS, PSSSE and PSSPE. Besides, multiple regression analyses identified the amount of variance in PSSRS explained by the components of PSSSE and PSSPE. The qualitative data were analyzed by transcribing interview notes, reviewing the transcripts of each interview session and organizing the data into themes that emerged during the fieldwork. Operationally, transcripts of the note-taking were summarized and documented in the process of coding chunks of data and showing relationships between categories or themes. Trustworthiness of the qualitative data were assured by obtaining rich data, member checking, data memoing and journal writing.

\section{RESULTS AND DISCUSSIONS}

\section{Quantitative Findings}

Two hundred questionnaires were distributed among the CPOs of eight police stations. One hundred and eighty questionnaires were filled and returned appropriately representing a 90 percent response rate. Therefore, the final subject sample of this study consists of 180 CPOs from different police stations. There are: 105 participants (58.3\%) from the police stations within SEZ and the rest (41.7\%) belong to the police stations within NSEZ. Among the respondents, males constitute just over 89 percent (161) of the sample, whereas females are only 10.6 percent (19) of the sample. The age of the respondents ranges from 23 to 52 years, with a mean age of $34.59(S D=6.79)$ years. The subjects report levels of education with primary school being the minimum. 14 respondents indicate that they are high-school graduates (4 graduated from junior high school and 10 graduated from senior high school), $162(90 \%)$ are university undergraduates and have an associate degree or a bachelor degree and 3 respondents (1.7\%) indicate that they have pursued the postgraduate studies. It should be pointed out that 52.2 percent of the respondents graduated form the police academy whereas 47.8 percent are graduated from the nonpolice academy. The respondents are also asked to indicate the number of years they have served in the police force. The number of years in service ranges from 1 to 31 with a mean of 11.53 years $(S D=6.92)$. The ranking of the participants ranges from Constable $\left(2^{\text {nd }}\right.$ Class) to Supervisor ( $1^{\text {st }}$ Class). Among them, over $28 \%$ belong to the rank of Supervisor ( $3^{\text {rd }}$ Class). Most hold rank of Superintendent (77) or Supervisor (101). Also, 0.6 percent is Constable ( $2^{\text {nd }}$ Class) and 0.6 percent was Constable ( $1^{\text {st }}$ Class). Table 3 provides the details of demographic characteristics of the sample including age, sex, education, graduation, current rank, police experience and working site.

\section{High Level of Police Social Service Role Strain}

The overall PSSRS score for the CPOs was determined by adding up the values for 6 items of the 
Table 3: Characteristics of the Sample $(\mathrm{N}=180)$

\begin{tabular}{|c|c|c|c|}
\hline \multicolumn{2}{|c|}{ Demographic Variable } & $\mathbf{N}(\%)$ & $M(S D)$ \\
\hline \multicolumn{2}{|c|}{ Average age (Years) } & & $34.59(6.79)$ \\
\hline \multicolumn{2}{|c|}{ Average years of police experience } & & $11.53(6.92)$ \\
\hline \multirow[t]{2}{*}{ Sex } & Male & $161(89.4)$ & \\
\hline & Female & $19(10.6)$ & \\
\hline \multirow[t]{5}{*}{ Education } & Primary school & $1(0.6)$ & \\
\hline & Junior high school & $4(2.2)$ & \\
\hline & Senior high school & $10(5.6)$ & \\
\hline & Undergraduate & $162(90)$ & \\
\hline & Postgraduate & $3(1.7)$ & \\
\hline \multirow[t]{2}{*}{ Graduation from the police academy } & Yes & $94(52.2)$ & \\
\hline & No & $86(47.8)$ & \\
\hline \multirow[t]{8}{*}{ Rank } & Constable, $2^{\text {nd }}$ Class & $1(0.6)$ & \\
\hline & Constable, $1^{\text {st }}$ Class & $1(0.6)$ & \\
\hline & Superintendent, $3^{\text {rd }}$ Class & $23(12.8)$ & \\
\hline & Superintendent, $2^{\text {nd }}$ Class & $24(13.3)$ & \\
\hline & Superintendent, $1^{\text {st }}$ class & $30(16.7)$ & \\
\hline & Supervisor, $3^{\text {rd }}$ Class & $52(28.9)$ & \\
\hline & Supervisor, $2^{\text {nd }}$ Class & $40(22.2)$ & \\
\hline & Supervisor, $1^{\text {st }}$ class & $9(5)$ & \\
\hline \multirow[t]{2}{*}{ Location of the police station } & Shenzhen Special Economic Zone & $75(41.7)$ & \\
\hline & Non-Shenzhen Special Economic Zone & $105(58.3)$ & \\
\hline
\end{tabular}

Police Social Service Role Strain Scale. A seven-point Likert scale is used for the responses with the response categories of 1 (very strongly disagree) to 7 (very strongly agree). Considering that the possible range of PSSRS is 6 to 42, the participated CPOs seems to report a relatively high mean level of PSSRS, a mean of $34.92(S D=2.19)$, with a score range from 29 to 41 (Table 4). The descriptive statistics of PSSRS is likely to establish that the participants are suffering from PSSRS.

In order to investigate whether there are significant differences in PSSRS due to personal characteristics, the independent $t$-test was conducted. The results were as follows.

1) There was an insignificant difference between male $(M=34.96, S D=2.17)$ and female police officers $(M=34.58, S D=2.34)$ on PSSRS ( $t=$ $-.71, p=.48)$.

2) There was an insignificant difference between police officers with police academy graduation $(M=34.97, S D=2.22)$ and police officers with nonpolice academy graduation $(M=34.86, S D=2.16)$ on PSSRS ( $t=.33, p=.74)$.

3) There was an insignificant difference between police officers with higher rank ( $M=34.68$, $S D=2.28)$ and police officers with lower rank $(M=35.22, S D=2.05)$ on PSSRS $(t=1.63, p=$ $.11)$.

4) There was an insignificant difference between police officers within SEZ $(M=35.23, S D=2.27)$ and police officers within NSEZ ( $M=34.70$, $S D=2.11)$ on PSSRS $(t=1.61, p=.10)$.

Table 4: Descriptive Statistics of PSSRS among Participants

\begin{tabular}{|c|c|c|c|c|}
\hline Instrument & Possible Range & Score Range & M & SD \\
\hline Police Social Service Role Strain (PSSRS) & $6-42$ & $29-41$ & 34.92 & 2.19 \\
\hline
\end{tabular}


The independent $t$-test results indicated that there were no differences in PSSRS due to personal characteristics.

\section{Low Level of Police Social Service Structural Empowerment}

Nineteen items in the Police Social Service Structural Empowerment Scale were used to analyze structural empowerment level of frontline CPOs. Laschinger et al. (2001) grouped these items into six subscales: opportunity (3 items), information (3 items), support ( 3 items), resources ( 3 items), formal power ( 3 items) and informal power (4 items). These participated CPOs rated their perceptions of structural empowerment on a five point Likert scale that ranged from 1 (none) to 5 (a lot). Considering that one subscale had a different number of items, the sum of data of each subscale was divided by the number of items for comparison among these subscales. The mean and standard deviation of PSSSE were 11.08 (on the possible range of 6-30) and 3.09, which seemed to show that CPOs had low levels of PSSSE. For the six subscales of PSSSE, CPOs had the highest mean score on information (mean score of 2.28), and the lowest score on resources (mean score of 1.62). The mean values, possible range and standard deviation of PSSSE are presented in Table 5.

In order to investigate whether there are differences in PSSSE due to personal characteristics, the independent $t$-test was conducted. The results were as follows.

1) There was an insignificant difference between male $(M=35.29, S D=4.19)$ and female police officers $(M=35.11, S D=4.86)$ on PSSSE ( $t=$ $-.18, p=.86)$.

2) There was an insignificant difference between police officers with police academy graduation $(M=35.40, S D=4.26)$ and police officers with non- police academy graduation $(M=35.12, S D=4.26)$ on PSSSE $(t=.45, p=.65)$.

3) There was an insignificant difference between police officers with higher rank $(M=35.00$, $S D=4.39$ ) and police officers with lower rank $(M=35.48, S D=4.15)$ on PSSSE $(t=-.74, p=$ $.49)$.

4) There was an insignificant difference between police officers within SEZ $(M=34.59, S D=3.50)$ and police officers within NSEZ $(M=35.75$, $S D=4.67)$ on PSSSE $(t=-1.82, p=.07)$.

The independent $t$-test results indicated that there were no differences in PSSSE due to personal characteristics.

\section{Low Level of Police Social Service Psychological Empowerment}

The Police Social Service Psychological Empowerment Scale was used to measure the level of overall psychological empowerment. Spreitzer (1995) grouped these items into four subscales: meaning (2 items), competence (2 items), self-determination (3 items) and impact (2 items). A seven Likert scale from 1 (very strongly agree) to 7 (very strongly disagree) was used in the scale. Considering that one subscale had a different number of items, the sum of data of each subscale was divided by the number of items for comparison among these subscales. Generally, the means of PSSPE was likely to show that the CPOs had a weak sense of psychological empowerment $(M=12.08, S D=2.87$ with a possible range of $4-28)$. Among the PSSPE subscales, the score of meaning (mean score of 4.03) was the highest and that of impact (mean score of 1.95) was the lowest. The results are shown in Table 6.

In order to investigate whether there are significant differences in PSSPE due to personal characteristics,

Table 5: Descriptive Statistics of PSSSE among Participants

\begin{tabular}{|c|c|c|c|}
\hline Instrument & Possible Range & M & SD \\
\hline Police Social Service Structural Empowerment (PSSSE) & $6-30$ & 11.08 & 3.09 \\
\hline Support & $1-5$ & 1.67 & 0.44 \\
\hline Information & $1-5$ & 2.28 & 0.41 \\
\hline Resources & $1-5$ & 1.62 & 0.41 \\
\hline Opportunity & $1-5$ & 1.85 & 0.39 \\
\hline Formal Power & $1-5$ & 1.64 & 0.40 \\
\hline Informal Power & $1-5$ & 2.02 & 0.53 \\
\hline
\end{tabular}

Note. $\mathrm{M}=$ Mean; $\mathrm{SD}=$ Standard Deviation. 
Table 6: Descriptive Statistics of PSSPE among Participants

\begin{tabular}{|c|c|c|c|}
\hline Instrument & Possible Range & M & SD \\
\hline Police Social Service Psychological Empowerment (PSSPE) & $4-28$ & 12.08 & 2.87 \\
\hline Meaning & $1-7$ & 4.03 & 1.01 \\
\hline Competence & $1-7$ & 3.21 & 0.96 \\
\hline Self-determination & $1-7$ & 2.89 & 1.57 \\
\hline Impact & $1-7$ & 1.95 & 0.80 \\
\hline
\end{tabular}

Note. $\mathrm{M}=$ Mean; $\mathrm{SD}=$ Standard Deviation.

the independent $t$-test was conducted. The results were as follows.

1) There was an insignificant difference between male $(M=27.09, S D=2.89)$ and female police officers $(M=26.68, S D=2.73)$ on PSSPE ( $t=$ $-.58, p=.57)$.

2) There was an insignificant difference between police officers with police academy graduation $(M=26.91, S D=2.85)$ and police officers with nonpolice academy graduation $(M=27.19, S D=2.91)$ on PSSPE $(t=.63, p=.53)$.

3) There was an insignificant difference between police officers with higher rank $(M=27.45$, $S D=2.69)$ and police officers with lower rank $(M=27.53, S D=2.63)$ on PSSPE $(t=-1.14, p=$ $.34)$.

4) There was an insignificant difference between police officers within SEZ $(M=27.07, S D=2.55)$ and police officers within NSEZ $(M=27.74$, $S D=2.52)$ on PSSPE $(t=-1.02, p=.17)$.
The independent $t$-test results indicated that there were no differences in PSSPE due to personal characteristics.

\section{The Significant Relationships between PSSSE, PSSPE and PSSRS}

Except for impact, support and formal power, the results of all hypotheses tests demonstrate that all dimensions of PSSSE $(r=-.35, p<.01)$ and $\operatorname{PSSPE}(r$ $=-.42, p<.01)$ and the gestalts are significantly and negatively correlated with PSSRS. Considering that a majority of the hypotheses ( 9 are accepted and 3 are rejected) in this study are accepted, there is substantial evidence of this study supporting the existence of the significant relationships between PSSSE, PSSPE and PSSRS. The following (Table 7) is a matrix summarizing the hypotheses test results.

\section{The Relative Contributions of PSSSE and PSSPE}

With the help of simultaneous multiple regression method, this study tested the hypotheses that PSSSE and PSSPE would predict PSSRS. It also showed how

Table 7: Summary of Results of Hypotheses Test

\begin{tabular}{|c|c|}
\hline Hypothesized Significant Association & Police Social Service Role Strain (PSSRS) \\
\hline \hline Police Social Service Structural Empowerment (PSSSE) & $r(180)=-.35^{* *}$ \\
\hline Support & $r(180)=-.18^{* *}$ \\
\hline Information & $r(180)=-.34^{* *}$ \\
\hline Resources & $r(180)=-.19^{* *}$ \\
\hline Opportunity & Rejected \\
\hline Formal Power & $r(180)=-.18^{* *}$ \\
\hline Informal Power & $r(180)=-.42^{* *}$ \\
\hline Police Social Service Psychological Empowerment (PSSPE) & $r(180)=-.40^{* *}$ \\
\hline Meaning & $r(180)=-.29^{* *}$ \\
\hline Competence & $r(180)=-.30^{* *}$ \\
\hline Self-determination & Rejected \\
\hline Impact & \\
\hline
\end{tabular}

Note. ${ }^{*} \mathrm{p}<.05,{ }^{* *} \mathrm{p}<.01$ 
Table 8: Simultaneous Multiple Regression Analysis for PSSWE, PSSPE and PSSRS ( $\mathrm{N}=180)$

\begin{tabular}{|c|c|c|c|}
\hline Variable & $\boldsymbol{\beta}$ & $\mathbf{t}$ & Sig \\
\hline \hline PSSSE & -.13 & -1.53 & $<.05$ \\
\hline PSSPE & -.26 & -3.20 & $<.01$ \\
\hline Constant & & 8.70 & \\
\hline
\end{tabular}

Note. Dependent Variable: PSSRS; $R^{2}=.22 ; F(1,178)=16.58, p<.001$.

variance of PSSRS could be explained by PSSSE and PSSPE taken together. Table $\mathbf{8}$ shows that the multiple correlation coefficient $(R)$, using all the predictors simultaneously, is .47 $\left(R^{2}=.22, F[1,178]=16.58, p<\right.$ $.001)$. It is noted that $22 \%$ of the variance in role strain can be predicted from structural empowerment and psychological empowerment. The result indicates that PSSSE and PSSPE significantly predict PSSRS.

\section{Qualitative Findings}

The nature of PSSRS experienced by the interviewees in the police station was psychological, emotional or mental. Although the majority of interviewees (9 or $75 \%$ ) found it difficult to describe their state of mind or feeling towards the social service role, the distressful psychological experiences that interviewees generally described were evident in insomnia, nervousness, discomfort, fatigue, frustration, discomfort, irritation and perplexity. All interviewees experienced at least one of the above symptoms on a daily basis. These comments provided by the interviewees suggested that social service work in the police stations could manifest as psychological distress among CPOs.

\section{Insomnia}

Six interviewees (50\%) described that one symptom of PSSRS was insomnia. They mentioned that they could not sleep well at night due to the preoccupation with the events concerned with social service work. One interviewee (CPO4) said the following:

The social service role is frustrating for me .... You're a researcher, you probably understand this kind of feeling a lot better than a lay person. Sometimes, I spend my nights up suffering from insomnia because I am ruminating about many problems of social service work.

\section{Nervousness or Stress}

Five interviewees $(41.6 \%)$ indicated that they fairly often felt nervous or stressed by social service work.
They felt that social service work was too stressful to adapt well. They asked if they could take more time to orient to the stressful working environment or to take a break in order to prepare them better for challenging social service work. One interviewee (CPO9) stated, 'I am ill at ease, not at ease, under pressure....'

\section{Perplexity}

Three interviewees (25\%) reported that they frequently felt perplexed by the social service role. One interviewee (CPO9) described, 'I feel trapped and blocked, I do not know what to do'.

\section{Irritation}

It should be noted that ten interviewees (83.3\%) reported that they were unable to control agitations in social service work. They revealed irritability when dealing with others. They might have outbursts, including insults and offensive language. These irritated emotion in turn created further strain regarding social service work. One interviewee (CPO10) expressed, 'I was kind of angry. I got a feeling inside like I was going to burst'.

\section{Discomfort}

Eleven interviewees $(91.7 \%)$ noted the feeling of discomfort in social service work. One interviewee (CPO12) revealed, 'I think one of the most obvious manifestations of this kind of PSSRS was daily psychological discomfort, particularly in the police station'.

\section{Depression or Frustration}

Seven interviewees $(58.3 \%)$ reported a feeling of depression or frustration in social service work. One interviewee (CPO11) described his experience of the down feeling as follows:

I was impatient with everybody; I didn't want anyone to approach me. Just leave me alone! I feel sad..., I was frustrated and depressed. 


\section{Fatigue}

Nine interviewees (75\%) noted that social service work caused them to feel fatigued, even exhausted. One interviewee (CPO1) described, 'I feel tired... kind of cannot do it (social service work) anymore. You know, as time goes by, it went from tiredness to exhaustion'.

\section{Paramilitary-Bureaucratic Structure: Poor Communication and Information Flow and Support}

\section{A Pyramidal Organizational Structure}

The administration of the Chinese police organizations is based on the pyramidal organizational structure containing the elements of paramilitary and bureaucracy: specialized functions, sticking to rigid regulations, and a vertical hierarchy of authority. The police organizations are tall, hierarchical, paramilitary bureaucracies. Most police organizations are shaped like a pyramid, with many layers of command separating the top command from the frontline officers at the bottom. The rank structure of a police station in Shenzhen, China, for example, consists of a hierarchy that takes the shape of a pyramid. Authority decreases as one descends in rank. The director sits at the peak in the organization. Directly below the director is the deputy director. The police station usually has a supervisor of personnel affairs, who represents the second-in-command person. Borrowing heavily from the military terminology, the rank structure in a police station may consist of sergeant and police officer. The relationships among organization members are presumed to follow this pyramidal structure:

1) Almost all contacts are conducted by taking the form of orders going downward and reports of results going upward.

2) Receiving instructions and orders from one superior, the individual officers at any level (except at the top and bottom) have direct contact only with their superior above them and their subordinates below them.

3) Important decisions are made at the highest point of the pyramid due to most of the power resideing with the top management.

4) Tall organizations have many intermediate ranks between the top and the bottom and operate on a defined chain of command (Roberg \& Kuykendall, 1990).
It should be noted that this steep pyramidal structure, characterized by many hierarchical levels, often makes police stations dysfunctional by minimizing or eliminating human interactions among different ranks.

\section{A Rigid Chain of Command}

Police organizations have a vertical differentiation that refers to a rigid chain of command. The superiors have complete authority over subordinates. Each police officer has a rank and is obliged to take orders from those who outrank him/her. This rigid arrangement of roles denotes the authority or control that each incumbent possesses over other police station members. Sergeants in a police station, for example, supervise line-level police officers. In turn, sergeants are accountable to deputy directors vested with a higher rank.

This rigid chain of command determines the nature of formal or informal interaction within a police station. Generally speaking, one-way, trickle-down flow of directives or orders is commonly conducted within the rigid command structure. This top-down approach is the typical paramilitary-bureaucratic model that involves a downward flow of communications and information. In a police station, for example, the director or deputy director, along with his or her inner circle of advisors, formulate policy, rules, and regulations. Policies, rules and regulations typically flow from the top down, and obedience is expected among supervisors, who are responsible for implementation, and frontline officers, who are responsible for adhering to these standards. During the process of communication and information flow, the police administrators 'use primarily one-way communication from the management to the line function, passing through various levels of hierarchy, with the power and decision making vested at the top' (Reiter, 1999, p.7). The pyramidal organization structure often fails in trying to promote open and constructive communication horizontally (within the police organization) as well as laterally (among the multi-agency).

First, communication within the organization often 'breaks down' (Walker \& Katz, 2008, p.98). The police organization uses a closed form of communication. The director and the top management in a police station, for example, are supposed to have wisdom and vision about the policing so they are provided with the power to issue orders to reach planned objectives. When a 
decision must be made, the management considers only its own view in reaching that decision. The knowledge and views of frontline police officers are frequently ignored. The management is unresponsive and does not keep in touch with the frontline police officers. This form of communication not only separates the administration from the officers, but it also reinforces the isolation among frontline officers. The rigidity of the chain of command blocks the upward flow of ideas at the line-level for there is little tolerance for ideas originating at the bottom of the pyramid. Communication and innovative ideas are thwarted, distorted or even prematurely stopped due to the tall pyramid design of organization. Important and precise information tends to be unreachable for the frontline police officers who need it. As a result, bad decisions are made, or the organization pursues conflicting goals.

Second, the pyramidal structure is also said to be uncommunicative laterally (Roberg\& Kuykendall, 1990). It not only blocks effective communication within the organization because of the superior-subordinate relationship, but the necessary partnership and cooperative working relationship among multi-agencies are inevitably discouraged. This paramilitary organizational structure creates distance between police and mass organizations or other governmental departments and reduces opportunities for cooperation and partnership to solve complex social service problems.

Third, police administration within the pyramidal police organization is also accused of not catering to demands of frontline officers and being isolated from the frontline officers (Stevens, 2003). The professionalization movement has resulted in the police administrators becoming increasingly remote from the frontline officers. Although the management is expected to support the frontline officers, this is not the case in practice. The reality of the situation is that the management continually tries to control the behavior of frontline officers. The problem of isolation is particularly acute with respect to superior-subordinate relations, as police administrators have been accused of not listening to the concerns of frontline officers. The police station, for example, lacks effective means to settle disputes between different ranks or divisions (e.g. the Community Patrol Team and the Case Investigation Team). The lack of support within the police station tends to be neglected due to mistrust, fear of reprisals and gossip, and so on.

\section{Resources Allocation Structure: An Inverted Pyramid}

The top-down pyramidal structure is far too centralized. Resources (manpower and equipment) are allocated according to plans drawn up at the top management, and the line-level officers who are in closest contact with operational problems have little opportunity to shape policy (Palmiotto, 2000). Taking the shape of an 'inverted pyramid', the resource disposition structure of the Chinese police organization is particularly problematic at the lowest police rank.

China has a comparatively low police-population ratio (1.38/1000) (Zhong, 2009). The task of community participation, emergency response and patrol are mainly carried out by the frontline officers of police stations. Despite the fact that the police station is the place where most of the police-people contacts take place, the police stations are limited to a small scale in terms of manpower and equipment. One director of a police station once complained that:

[W]e have discussed the problem of simplifying structures and strengthening grass root organizations for many years. However, the more we talk about simplification, the more colossal the structure is, the more centralized the power is, and the more serious is the phenomenon of 'converse triangle' in man power and equipment. Therefore, many comrades say that the [police station] reform is to dump more tasks on the [police station] police and transfer more resources to the superior organizations (as cited in Fu, 1990, pp.112-113).

The problem of manpower and equipment shortage has a direct impact on police social service work. Police social service work cannot be successfully accomplished without changing the resource disposition structure. In his discussion of the current police organization, $\mathrm{Hu}$ (as cited in $\mathrm{Fu}, 1990$, p.113) emphasizes the importance of empowerment in terms of resources to the police station, to provide a balance among its responsibility, authority and interests.

As the [police station] is the basic unit in the police system, its reform is necessarily related to the public security organs at the higher levels. If the system and work method in the superior organs remain the same, the [police station] reform cannot be 
successful. It is therefore beneficial for the [police station] reform to simplify the upper levels, to strengthen the grass root units and to decentralize the authority to the [police station].

Most of social service work is still done by the under-manned police stations with deficient equipment, whose interests are often not taken into consideration. Complaints from the frontline officers have been mounting. They argue that police professionalization only increases their burden and does not touch the problematic paramilitary-bureaucratic structure (Fu, 1990). In the current study, I found that a sample of CPOs perceived greater problems associated with the problematic pyramidal police organization: lack of information, support, informal power and resources.

\section{Lack of Information}

Several important areas of concern for participants were suggested: these included lack of information from the dispatcher, over used downward communication and inconsistent policy and wrong distribution.

\section{Insufficient Information from the Dispatchers}

Seven participants (58.3\%) complained about making decisions without sufficient information from the dispatcher in social service work. They generally felt they did not get enough information to do their social service work. To some extent, the CPOs had to rely on the dispatcher's information for they are the key sources of information for CPOs. Dispatchers, being 'white collars' (office workers), were deemed to be poorly informed about front line police realities. Therefore, failures to be fully informed of the information were a frequently recurrent problem for the CPOs. One participant cited one example to illustrate this point: 'There may be a call for social service in the district next to you, but the information is not passed on. The problem may end up in your area, but you won't know.'

\section{Overused Downward Communication}

Five participants $(41.7 \%)$ suggested that the information flowing should be adapted due to the overused downward approach. The information-sharing between the superior and the frontline officers was very important for the success of social service work and the enhancement of the CPO's profession. But, the downward communication approach is overused in the police organization. One participant complained: 'The supervisors normally give out orders, and the streetlevel CPOs just follow. It is often unclear and can lead to superiors' lack of regards for subordinates'. Another participant suggested: 'The information should also flow in a bottom-up way'.

\section{Inconsistent Policy and Wrong Policy Distribution}

Six participants $(50 \%)$ indicated problems of inconsistent policy and wrong policy distribution in social service work. Since the decision-making was untransparent, participants frequently complained that the policies were inapplicable in the operational field and inconsistent. This problem then created more confusion among CPOs. One participant noted that rules or regulations related to the social service work got changed frequently.

There were some miscommunications during the policy distribution. The conflicts and misunderstanding between superiors and the frontline CPOs became worse during the process of policy distribution. One participant complained that the commanders sometimes distributed contrary and confusing messages to the subordinates in the police station.

\section{Lack of Support}

It appeared that most participants had the experiences of receiving poor or inadequate support from colleagues and superiors and a weak sense of trust within the organization. Participants generally viewed their work environment to be unsupportive and that both supervisors and fellow officers within the organization had very little concern for their well-being.

\section{Lack of Collegial Support}

Eight $(66.7 \%)$ participants described their experience of working with unsupportive colleagues or inadequate collegial support. They further mentioned that colleagues were generally not very helpful and that there is a real tendency to adopt a careless attitude in the police stations. Two participants reported their typical experience relating to unsupportive fellow officers. One of them said:

One day, one of my colleagues told me that I needed to take things easy. He suggested that I do not need to pay too much attention to some minor issues of social service work. He told me that I might have an obsessive-compulsive disorder. What was that? He should give me support, not make a diagnosis. 


\section{Lack of Support from the Management}

Nine participants $(75 \%)$ noted that they did not receive much support from both their immediate supervisors and the police administrators. They felt humiliated and separated from superiors or police administrators, who were reluctant to offer an opinion or support. One participant described his disappointment and frustration towards his supervisor:

I think that the person that has the most effect on your life is the person who is immediately ahead of you, the first person you have to report to; your immediate supervisor has the biggest impact in your life. Sometimes more than your family. . . . But my supervisor is making my life miserable. I'm not getting what I think I need or he's not helping ....

\section{Lack of Trust}

Although there was, in general, a lack of collegial and management support from the police station, most participants were unwilling to seek support in the environment of a lack of trust toward their colleagues and superiors. Lack of trust among colleagues, or between subordinates and superiors, was obvious in the police station. Frequently, they had to be very careful who they spoke to. One participant noted with caution: 'At the time you think you can trust these people. And I will tell you that probably the only person you can trust now is yourself'.

\section{Lack of Resources}

According to the participants, few resources were available for the social service work and the limited resources within the police station led to frustrations regarding the CPOs' ability to do the job in an effective way. The police stations became overloaded due to the resource shortages.

\section{Equipment Insufficiency}

Ten participants (83.3\%) identified PSSRS caused by the equipment insufficiency. This often created conflict within the police station. The primary problem was a lack of essential equipment due to the restricted financial environment in which CPOs worked. CPOs lacked the modern and up-to-date equipment, such as police vehicles and first-aid equipment. The interviewees emphasized that the effects of the financial cutbacks in the police station, such as being short of essential equipment, affected their work.
Assessing and prioritizing the calls for social service were difficult when resources were limited.

\section{Manpower Insufficiency}

Eleven participants (91.7\%) reported that insufficient manpower to adequately handle social service work caused them to feel strain. According to one participant, most police stations in Shenzhen were small in number of CPOs. For example, of the approximately 74 police stations in the NSEZ, $90 \%$ of the police stations had around 30 CPOs or fewer in their employment. When it came to social service work, the paid security guards (employed by the police stations) and some volunteers or social workers actually played much more important role due to the personnel insufficiency in the police stations. Moreover, the police stations in the NSEZ police an area that was on average about 25 square miles in size. However, social service work was often done with less CPOs than those in the SEZ, making the CPOs' duties more difficult due to the large size of the police area within the NSEZ they patrolled. One participant gave one example to illustrate this point:

Due to the rather confined space geographically, the comparative high number of CPOs and resources, officers in the SEZ will generally have a backup on calls for social service that is within a 5minute response. In the NSEZ, due to the large geography, a comparative low number of officers and a lack of resources, CPOs may have no backup readily available and the response time can sometimes be much longer.

\section{Lack of Informal Power}

Lack of inter-personal communication between superior and subordinate, lack of communication among peers, and deficient multi-agency cooperation (between the police and other organizations) were identified by the participants as factors that influenced PSSRS.

\section{Lack of Communication between Superior and Subordinate}

Ten (83.3\%) participants reported that they tended to become distressed because of the lack of communication between superior and subordinate. According to one participant, the leadership of police stations was too distant and insufficiently concerned with the problems of the frontline CPOs. The police 
administrators were described as having lost touch with the frontline officers. It appeared that the police administrators had no clues about what social service work was like. When asked for suggestions, two participants believed that improvements on organizational communication between the police administrators and CPOs could be made. One of them said:

We do need recognition and respect from the superior. It is of no use to sit at the office with complaints. What we can do is just stand up to use effective communication channels to discuss with our superiors. In this way, the police administrators can understand and identify the significance of our social service work.... We should speak out for ourselves in an appropriate way; if not, CPOs' work will never be fairly compensated.

\section{Lack of Communication among Peers}

When the conversation turned to the interpersonal communication among peers, nine participants (75\%) mentioned their frustrating experience of poor relationships. One participant mentioned that being assigned to work with a difficult or incompatible partner who was uncommunicative made him feel distressed. He said, 'I am the unlucky one that particular time to be with some terrible partners. There are some people that you get in the police car who don't talk the whole day that you are with them....'

\section{Deficient Multi-agency Communication}

Communication with other organizations is important for the success of the police organization and the enhancement of social service work. Communication can facilitate task coordination, provide a means of sharing information, provide a channel of communication for problem solving, and facilitate mutual support for CPOs. However, eight participants $(66.7 \%)$ reported a lack of multi-agency communication. They also highlighted that the police should pay attention to the lack of CPO's experience with other occupational groups.

According to one participant, professionals within the social service area (e.g. social welfare officers, social workers, the police) should not work in isolation. Coordination across and within organizations was needed to compile all efforts. Growing awareness by the frontline CPOs that the police were not the only agency to deal with the variety of social service work had led to the development of multi-agency cooperation.

\section{Paramilitary-Bureaucratic Structure: Disregard of the Personal Development}

'Management always should value all employees based on the skills and potential they possess. It remains the organization's responsibility to provide an environment that allows them to reach their potential' (Reiter, 1999, p.9). The paramilitary-bureaucratic police organization frequently fails in this regard by inadequately allowing for the personal growth and development regarding the expertise and personalities. It has been accused of being inflexible, inefficient, and insensitive to needs of individual police officers for it stifles the individual freedom, spontaneity, and selfrealization as well as individual creativity, skills, and potentials (Pelfrey, 1998).

\section{Negligence of the Individual Police Officer}

According to Ford (2002), it has been acknowledged that the paramilitary-bureaucratic model of police organization definitely downgrades the position of the individual officer in the police force. 'Too often the basic police officer is viewed as comparable to a solider in the military, the lowest ranking military person' (Meese, 1993, p.3). The individual officer is expected: 1) to obey the orders of the superior; 2) not to display extensive initiative, discretion, adaptability and creativity in the performance of his/her duties; 3 ) to function effectively as part of a larger unit; 4 ) to perform tasks in a precisely prescribed manner; and 5) to be uniform in his/her appearance, conduct, and behavior. These organizational restrictions on personal freedom of performance, expression, association, and dress have been criticized for they create a mindset and rigidity on the police officer's role (Peak, Gaines \& Glensor, 2010). Such uniformity is depersonalizing and inappropriate for the police service (Roberg \& Kuykendall, 1990). 'It is little wonder, then, that those holding the lower rank of police officer often are regarded as somebody less than professionals' and that they are frequently denied or ignored the individual authority, creativity, flexibility and adaptability that would normally accompany professionals (Meese, 1993, p.3).

\section{Discouragement of Innovation, Flexibility and Adaptability}

The paramilitary-bureaucratic police organization has been known to stifle individual innovation within the 
organization and promotes a lack of flexibility and adaptability (Peak, Gaines\& Glensor, 2010). The paramilitary-bureaucratic structure with an emphasis on rules and regulations creates impediments to the adoption of new ideas when they run counter to policy, accepted practice, or tradition. The innovative ideas are frequently labelled 'unworkable' and discarded before they have a chance (Palmiotto, 1999, p. 223).

In the paramilitary-bureaucratic police organization, the frontline officers learn to focus on rules rather than on service. They frequently respond to many requests for assistance with phrases like, 'It's not in my job description or it's beyond my authority'. This can be called objective displacement. That means the frontline officers tends to play by the rules by focusing on what not to do rather than what to do and how to do it, even if it makes sense to them to do it. As a result, the paramilitary-bureaucratic police organizations are not inclined to be innovative for the frontline officers do not use information about the environment properly and are inclined to rigidity.

The paramilitary-bureaucratic police organizations are accused of not using the talents of the frontline officers and matching talents to positions. One major problem among frontline police officers is that promotional opportunities are relatively few and career development and mobility has not been concerned. The police stations, for example, do not provide frontline officers with greater opportunities at work and more flexibility to perform their duties.

It seems that the structure and rigidity of rules within the paramilitary-bureaucratic police organization prevent personal development in terms of flexibility, adaptability, creativity and appropriate promotion. All of these problems suggest that the Chinese police organization should reassess its current approach to organizational design. This holds important implications for the frontline CPOs in this study. I found that the participants perceived two problems concerned with their personal development: lack of opportunity and lack of informal power.

\section{Lack of Opportunity}

\section{Little or No Room for Promotion}

Nine $(75 \%)$ of participants reported that there was little or no room for promotion in the police station. Failure of promotion at an anticipated time might result in feelings of depression and frustration. When CPOs' hard efforts on social service work did not lead to opportunities for rewards, such as money or promotion, the results could be irritability and prolonged depression. One participant described his situation as follows:

Even if you work hard, there is no incentive, I mean the promotion. The last three years working as a CPO, I have not been home very much. I might as well live in the police station because I'm here all the time. But it doesn't matter when it comes to promotion.... I have to learn to accept it, although it is painful.

\section{Immobility or Negative Career Development}

Many participants stated that immobility and negative career development could cause PSSRS in the police station. The police station was frequently procedurally inflexible and could not provide appropriate positions to make use of officers' potential. One participant suggested that the police organization should change to assist realization by providing opportunities for police officers to acquire the necessary skills and knowledge and the appropriate discretion to apply it due to the fact that many CPOs could research solutions and develop expertise that could benefit the organization. His accounts were as follows:

Just as an example, we have many experienced CPOs here, one is skilled with the computer, but he is not utilized whatsoever. If we utilized a lot of people's potential, CPO A is car geniuses, utilize that, $\mathrm{CPO} B$ is a computer genius, utilize that, you know what I mean. . . CPO C has done a lot for us, you can't deny him that. I think he deserves promotion. I am just saying that if we use people's potential, instead of worrying about who is going to look better than me, that's important.

\section{Lack of Formal Power}

It seemed that the visibility, creativity, flexibility and adaptability of the CPOs' social service work were not properly recognized and evaluated and led to CPOs' desensitization towards the formal power in the police station. That meant the access to formal power could not provide an appropriate channel for achievement that built CPOs' dignity, fulfilled their personal needs for growth and alleviated the level of their PSSRS. 


\section{Lack of Concern from the Management}

Eight participants $(66.7 \%)$ complained the lack of concern from the management. It appeared that the administrators or supervisors were insensitive, indifferent and non-evaluative to their social service work in the police station. As one participant explained:

I've heard several times that the supervisors or administrators aren't seeing my social service work, and I'm getting evaluated by these people who hasn't been on a social service call with me for a long time.... When you complete your social service work at the end of the day, who knows if you are doing it right or wrong? Supervisors? Administrators? No, they don't know what you are doing.

\section{Discouraging Work Environment}

Nine $(75 \%)$ participants indicated that the social service work environment discouraged their creativity, flexibility and adaptability. The work environment did not teach the CPOs respect for differences or engender the ability to handle social service work with creativity and innovation. It was better to be silent than to speak out. CPOs were scared about the potential negative consequences for voicing their creative or suggestive ideas regarding their social service work. According to one participant, he usually bore some of his personal, creative and suggestive ideas silently because he was afraid that if he spoke up, he might destroy the atmosphere at work. He even mentioned: 'The creativity of an officer is considered to be nothing. So now, if possible, I would like to be silent when I face any problem.'

\section{Desensitization}

Ten (83.3\%) of participants acknowledged a certain degree of desensitization towards the recognition, evaluation and discouragement surrounding the social service work environment. They even functioned in a careless social service work manner. That meant that they did not care about the access to formal power in the organization. The access to formal power, therefore, was not supposed to have an impact on PSSRS. One participant mentioned that it was hard to maintain his enthusiasm in social service work. He said that he actually did not need to do a really good job or make any improvement in social service work for being a CPO was just his occupation. If he focused too much on the evaluation and results, it did not seem to help. So nothing happened that bothered him very much.
Paramilitary-Bureaucratic Structure: Creation of Crime Fighter Mentality

The administration of the Chinese police organizations is based on the pyramidal organizational structure containing the elements of paramilitary and bureaucracy: specialized functions, sticking to rigid regulations, and a vertical hierarchy of authority. The police organizations are tall, hierarchical, paramilitary bureaucracies. Most police organizations are shaped like a pyramid, with many layers of command separating the top command from the frontline officers at the bottom. The rank structure of a police station in Shenzhen, China, for example, consists of a hierarchy that takes the shape of a pyramid. Authority decreases as one descends in rank. The director sits at the peak in the organization. Directly below the director is the deputy director. The police station usually has a supervisor of personnel affairs, who represents the second-in-command person. Borrowing heavily from the military terminology, the rank structure in a police station may consist of sergeant and police officer. The relationships among organization members are presumed to follow this pyramidal structure:

1) Almost all contacts are conducted by taking the form of orders going downward and reports of results going upward.

2) Receiving instructions and orders from one superior, the individual officers at any level (except at the top and bottom) have direct contact only with their superior above them and their subordinates below them.

3) Important decisions are made at the highest point of the pyramid due to most of the power resideing with the top management.

4) Tall organizations have many intermediate ranks between the top and the bottom and operate on a defined chain of command (Roberg \& Kuykendall, 1990).

The paramilitary-bureaucratic model of police organization has created and fostered a crime fighter mentality with a focus on crime fighting in the police organization (Purpura, 2001). Although such a strike hard culture fosters police solidarity, it tends to discourage social service work and development of close ties with the community of citizens that community policing seeks to create. The paramilitarybureaucratic police organization that develops with the professionalization has had a profound effect on police 
work. According to Palmiotto (1999, p.225), the paramilitary-bureaucratic organization:

nurtures an environment in which rewards and promotions are made on the basis of the number of outputs an officer achieved. In many cases, performance evaluations were weighted heavily on the number of cases, tickets, and arrests an officer obtained during a specific evaluation period. The message sent to frontline police officers was that maximizing the number of outputs (quantitative measures) was important to achieve recognition for a job well done.

This is problematic inasmuch as it has ignored the qualitative aspects of policing and police social service work, which are both important in a community policing approach. Although it is commonly believed that the police spend much of their time fighting crime, in reality, this is false: police actually spend most of their time helping citizens, maintaining order, gathering information, and promoting life quality of the community citizens (Walker \& Katz, 2008). Origniating from the military ethos, the frontline police officers cultivate an 'us versus them' attitude that is used to justify their ignorance and undervaluation of social service work and encourages the idea of 'strike hard' that is inappropriate for serving a citizen population.

In the paramilitary-bureaucratic police organization, personnel and resources are disposed on the basis of specialized needs. It is a general practice that most police stations are functionally and typically divided into several specialized units (e.g. Case Investigation Team) to fight against certain crimes in the major strike-hard setting. However, many police stations fail to deliver proper training and education, and to assist frontline officers in preparing for their social service work. Some police stations that are not as highly staffed for social service work do not provide adequate specialized and quality training for social service work and fail to cross-train staff in multiple areas (e.g. case investigation, patrol, emergency response and community participation). This method may cause the employees to lose sight and competence of police work as a whole by encouraging only some specific functions (e.g. crime fighting) on a micro level. In this study I found that a sample of CPOs perceived relatively serious problems of meaning and competence on social service work.

\section{Lack of Meaning}

\section{Undervaluation}

Nine $(75 \%)$ of participants reported that the CPOs' social service work was undervalued. They expressed that they disliked doing social service work for the social service role did not made them feel a great sense of accomplishment. Social service work was undervalued in comparison with other areas of police work. Although the participants felt that they had an obligation to faithfully do social service work as a CPO, the social service job did not have a great deal of meaning for them. Compared to the more highly valued activities of the criminal investigation branch or order maintenance branch, the police themselves placed a low value on social service work and gave little formal emphasis to the CPOs' social service role. The police tended to neglect the explicit recognition of their social service role. One participant (CPO8) mentioned the devaluation attitude among the frontline officers as follows:

The roles of the police are explicit in crime fighting and law enforcement but implicitly in the dimension of social service. Police officers, for a variety of reasons, often emphasized the crime fighting or law enforcement role and de-emphasize the social service role. This particular attitude is reflected in the common police expression, 'we are police officers, not social workers.' Their role as a social service provider is often denied by many police officers.

\section{Lower Priority Awarded}

Ten participants $(83.3 \%)$ perceived that they were disadvantaged in terms of working because social service work was awarded lower priority than crime investigation or order maintenance activities. Feelings of discouragement, resentment and depression were obvious among participants. One participant (CPO10) admitted that CPOs' social service work was not very glamorous and not a very popular topic. It seemed to be not very much concerned with policing. The policymakers or police administrators in the police department did not pay much attention to the CPOs' social service role.

\section{Lack of Competence}

\section{Feeling of Doubt and Uncertainty}

Eight participants $(66.7 \%)$ reported feelings of doubt and uncertainty during social service work. Social 
service work is the professional work that requires police officers to exercise considerable skill, make delicate decisions, and solve a wide range of interpersonal problems, with no hard-and-fast criteria about the correctness or incorrectness of solutions' (Toch, 2002, pp. 55-56). Therefore, frontline police officers frequently work with doubtfulness and ambiguity about some aspects of social service work. This situation ultimately makes the police officers question their own capability or competence and weaken their self-confidence. One participant (CPO8) mentioned the CPO's awkward situation as follows:

You know what strain is on this kind of social service job? Officers do not know they did it right or wrong. They don't know if they made the right choice or the bad choice. . . . This makes you feel uncomfortable on this job. You have to feel this job. There is nobody there to show you the answers. I mean, you get a situation, you have to solve this problem, sometimes you can't, but you have to do something, for example, to solve the dispute or find the missing persons or whatever. You can't just turn around and say, 'Well, this is too much for me. I can't take this.' and walk away. And you have to know how to handle people. But you know what? I have little faith in many of my fellow officers to properly do their job.

\section{Lack of Confidence}

Nine $(75 \%)$ of participants indicated that they felt unconfident frequently about their ability to handle the social service work problems. They found that they did not have enough skills and capability in social service work. According to one participant (CPO12), the CPOs' social service work was demanding, stressful, and unpredictable. However, CPOs only spent a few hours (around seven) to learn the essential social service techniques (such as interpersonal and problem-solving skills) during their training and orientation. Seven hours, actually, was not enough for CPOs to learn what they needed in the field operation. Social service work, indeed, challenged CPOs to show their work competence no matter how intellectual they were. Therefore, it was not surprising to see most CPOs were unconfident about their social service work competence.

\section{Paramilitary-Bureaucratic Operational Discretion Decision-Making \\ Structure: Limited and Participation in}

The Chinese economic reform has brought uncertainness and change in society. 'Information remains paramount, and policing, to some extent, has become an information business' (Reiter, 1999, p.8). The paramilitary-bureaucratic 'police organization worked well in a stable environment of performing largely similar tasks repetitively' (Reiter, 1999, p.8). However, as Chinese policing has moved from an environment of stability to the one with complexity and uncertainty, the paramilitary-bureaucratic structure of the police organization model seems to become dysfunctional.

\section{Limited Operational Discretion under Heavy Supervision}

With the development of professionalization in the Chinese police force, frontline police officers are controlled by internal rules and have limited authority for social service work. Paramilitary-bureaucratic organizations 'are grounded in rules and the legitimate exercise of hierarchical power' (Paul, 2001, p.474). Theoretically, frontline officers are supposed to make decisions by applying the prescribed rules in their area of police work. In practice, they have limited discretion in the field operation, and frequently make decisions based on strict compliance with the rules. It seems that the professional autonomy of the frontline officers to conduct social service work is lacking.

The police organizations impose formal control over police officers' behavior. The supervisors seek to control the frontline officers' behavior by heavy supervision. One important job of the superior is to see to that the frontline officers' conduct accords with the standing orders. Within the top-down approach communication structure, it is unsurprising to hear that 'you have to do this because I have told you so' in the police organizations.

\section{Authoritarianism in Decision-Making}

The Chinese police force has been adhering more closely to the autocratic leadership, with decisionmaking generally more concentrated at the peak of the hierarchy. The mission and goals of the organization are often set by the top-level management without soliciting or considering input from the frontline officers. For example, changing the police department's mission statement to implement the problematic policy of FHFS 
without considering inputs from frontline officers creates an atmosphere of resistance at the grassroots level. This sort of authoritative management style definitively leads to frustration, alienation with the avoidance attitude (Schmalleger\& Worrall, 2010).

\section{Necessity of Operational Discretion and Participation in the Decision-Making}

Limited discretion with heavy supervision and autocratic leadership is inappropriate for the broader, more autonomous role that is necessary with social service work. The modern police organization cannot only rigidly depend on a series of rules because the dynamic work environment frequently makes these rules to become outdated rapidly. In practice, frontline officers thus frequently make decisions that incongruent with existing rules (Paul, 2001). By trying to establishing rules designed for occurring problems, the paramilitary-bureaucratic police organization is simply too inflexible to adapt to external changes (Walker \& Katz, 2008). The supervisors and frontline officers display a lack of management flexibility in personnel decisions in the face of problems or situations that are not identified by existing guidelines, directions, or rules. Police stations have often failed to respond to changes in patterns of social service work and in the composition of the communities they serve.

Strict rules cannot be applied because of the nature of the social service work. Although the autocratic leadership and close supervision may be necessary in emergencies faced by police (e.g. serious crimes or accidents), often various routine situations and duties of social service wok should be handled by individual frontline officers with sufficient discretion and participation in the decision-making (Walker \& Katz, 2008). Also, strict orders are rarely required because most of social service work by frontline officers takes place on the street and out of the purview of supervisors. Frontline officers should be able to independently assess situations with creative, flexible thinking. As a result, if social service work is to be performed properly, a great amount of initiative and discretion are required.

\section{Emergence of Obedient Officers and Distrust}

The managerial philosophy reflected by the paramilitary-bureaucratic organization is characterized by an attitude of distrust, control, and punishment (Roberg, Novak, \& Cordner, 2009). Depending on rigid rules rather than the judgment of individuals reflects a lack of confidence and lower motivation. As Goldstein (1990, p.27) notes,
The dominant form of policing today continues to view police officers as automatons. Despite an awareness that they exercise broad discretion, they are held to strict account in their daily work for what they do and how they do it... Especially in procedural matters, they are required to adhere to detailed regulations. In large police agencies, rank-and-file police officers are often treated impersonally and kept in the dark regarding policy matters. Officers quickly learn, under these conditions, that the rewards go to those who conform to expectations - that non-thinking compliance is valued.

One of the most significant criticisms of the paramilitary-bureaucratic police organization is lack of motivation and confidence. The frontline officers in the police station lack motivation for social service work because of the psychological deprivation. That is, the organizational setting places police officers in a negative position where they have very little control over their social service work and are not involved in the decision-making of the police station.

Confidence 'is the essence of leadership in an empowered organization' (Reiter, 1999, p. 10). When frontline police officers 'think that their supervisors do not trust their judgment or do not put their talents to best use, most of their abilities, creativity, and intelligence are inactive, and policing becomes just a job to them' (Reiter, 1999, p.9). In the paramilitarybureaucratic police organizations, the judgment and decision-making abilities of frontline officers are frequently undervalued by the superiors. Removing decision-making from the frontline officers, the police management delivers a message that the organization has no trust 'in the judgment and ability of its officers but rather in sets of very detailed rules and regulations where strict compliance is expected' (Reiter, 1999, p.9). The paramilitary organization pays attention to control and organizational efficiency rather than people.

Given that the actions of supervisors and top command are viewed as arbitrary, there is a tendency to develop conformity and 'group thinking' among frontline police officers. This system may result in compliant employees who wait for and follow orders by acting only when so ordered. Also, individual police officers have become less positive in making suggestions and initiating changes in police 
organization and operations, and in dealing with new challenges in social service work. Discouraged by their superiors, the frontline officers have become less involved in the decision-making process associated with social service work and prefer to keep silence in the face of new policies or changes introduced by the management. In this study, I found that a sample of CPOs perceived relatively great problems of impact and self-determination in the police station.

\section{Lack of Impact}

\section{Lack of Influence over the Decision-Making}

In the police station, CPOs had little if any influence over command decisions or policy-making on the social service work.

\section{1) Lack of Participation in the Station-level Decision-} Making

Seven (58.3\%) participants stated that they did not have much experience in the station-level decisionmaking process. Given that the decision-making was not open and the management style was autocratic, frontline police officers know quite little about the process of decision-making conducted by police administrators. Usually, the director of the police station made the decisions, and then the CPOs were commanded to follow the decisions without any doubt. One participant (CPO1) expressed: 'In the police station, the director and deputy directors frequently make decisions. We are then given orders and carry them out after their decision-makings. They seldom ask our opinions.'

2) Limited Involvement in the Team-level Decisionmaking

Although they did have quite a few opportunities to be involved in the station-level decision-makings, nine $(75 \%)$ of participants reported that sometimes they were able to participate at the team-level (Community Patrol Team) decision-making by voting on decisions. However, oftentimes the decision-making options were screened first by the director or deputy directors. The director, actually, decided the extent of officers' involvement and made the final decisions.

According to one participant (CPO6), the decisionmaking in the CPT is conducted in a centralized approach since the sergeant preferred to listen to opinions of some selective core staff members' opinions rather than the majority of CPOs. Most CPOs, therefore, were not willing to express unfavorable opinions due to the fear of the powerful person. Actually, they fail to have the power to participate in decision-making.

\section{3) Expertise Being Ignored or Devalued}

Ten (83.3\%) complained about the administrators or supervisors who did not listen to suggestions and belittled CPOs in spite of their professional performance in social service work. What made them feel depressed was that most of the time the supervisors or administrators did not value CPOs' opinions. One participant (CPO12) noted: 'We are the persons who have close contact with citizens. Yet they (the police administrators) tend to ignore our voices when they make decisions. We are unable to express our professional opinions in an appropriate way.'

\section{Avoidance}

Avoidance coping strategy refers to 'the cognitive efforts to change the meaning of the situation, escaping or avoiding unpleasant thoughts by distancing one's self from the situation or self controlling' (Lazarus, 1993, p.260). It reflects attempts made to remove the strain source, psychologically or physically. The objectives of avoidance-coping include distracting the individual from the strain source and taking rational and effective actions to turn away from the stressful situation.

Although the participants were left out of the decision-making process and de-emphasized of the significance of their individual impact on the organization, it seemed clear that they got used to it and did not really care about their lack of control over their social service work outcome and impact on the organization. This is interesting, because the coping strategy of avoidance adopted by the participants implies that the impact was not supposed to have influence on PSSRS.

\section{1) Neglect}

Rather than trying to change aspects of their social service work environment, five participants (33.3\%) reported that they chose to cope by neglecting. These participants' coping strategies did not even mention the workplace, but relied on individual tactics to deal with an organizational issue. They focused their impact issues away from the job and actually did nothing to address the problem. Like one participant (CPO3) said:

You should accept in your roles to meet the demands of the social service work 
environment. Perhaps it is better to describe this attitude as the 'being relaxed and forget it' in that we know it is useless to complain and get strained or stressed about this too much.

\section{2) Self-control}

Seven participants (66.7\%) stated that they adopted self-control reactions towards being ignored in the police station. They experienced a progressive loss of belief in being able to make a difference in the police organization. The problem (lack of impact) still existed but there was nothing to be done because the problem was in the very nature of the work environment, which was difficult to change. As another participant (CPO7) reported:

I am quite aware of the fact that I cannot change the environment, but I can change how I react towards that environment. I realize that I have no control over the environment. I can only control my own feelings towards it. I do not care such kind of participation in the decision-making. It does not matter with me!

\section{Lack of Self-determination}

\section{Strict Adherence to Orders without Flexibility}

PSSRS was closely related to less direct control of social service work. The CPOs were offered little commensurate authority to accomplish the social service tasks. Therefore, officers tended to feel that they had little or no control over major decision-making of social service work on a personal level. The majority (10 or $83.3 \%$ ) of participants described their frustration with being told to strictly adhere to orders without flexibility and creativity in individually problematic situations. Although some police strategies (especially community policing) associated with social service work require an officer's independent action to resolve a specific community problem through empowered participation with community members, most CPOs involved with social service work actually hold little authority to fulfill the expectations of the job. CPOs were expected to be militaristic, submissive to authority, and follow policy and supervisory directions. Orders tended to be handed down from the top of the organization. A CPO seldom used his or her best judgment in resolving an issue. Obviously, there was a tremendous amount of disappointment and frustration among the CPOs for they had a limited amount of scope to do some of their social service work. According to one participant (CPO3), it was the frustration of knowing that he was being kept back from maximizing the skills that he had developed. He said:

There came a time when I was told that I could not work a case unless it was cleared specifically by the sergeant. I was very frustrated by that because in my mind I felt he had no sense of how to decide what case I could work and couldn't work based on what I knew.... I didn't feel that some of those decisions should be arbitrarily made by the sergeant ..., it was frustrating for me to have somebody else making decisions about the cases I should work when they had no expertise in what I did.

\section{Working under Close Scrutiny}

It seemed that little control or decision-making input over social service work influenced the CPOs' occupational behavior. Concerning their occupation and social service work that they performed, nine participants $(75 \%)$ indicated that they experienced close monitoring in their workplace, increasing the sense of powerlessness. They noted that fairly often they felt frustrated, angered, and distressed because of working under the close scrutiny. One participant (CPO1) described his experience: 'The sergeant put me on the patrol beat every night and checked on me every 30 minutes on his graveyard shift to make sure I was out there. I hated this kind of feeling!'

\section{Implications}

This study provides a new perspective on understanding the relationships between PSSSE, PSSPE and PSSRS among frontline officers. In order to make the police organization responsive, flexible, supportive and communicative in social service work, the current paramilitary-bureaucratic police organization needs to flatten its structure by reducing hierarchical levels and power decentralization. The police organizations need to provide a supportive work environment for frontline officers to reduce PSSRS in the following aspects:

\section{Offer Tangible Raises and Regular Recognition}

Given that opportunity for promotions and an upwardly mobile career path are relatively limited for the frontline officers in conducting social service work, the police administrators can use appropriate 
instructional strategies to facilitate the frontline officers' success by adopting the mentorship program for career development in social service work. The mentorship program may help frontline officers to pursue new opportunities that are necessary for officers' personal development. The career ladder for social service work, based on skill and knowledge development from novice to expert, can serve as a satisfying alternative to upward mobility. Attempts should be made to match the frontline officers with their interests, expertise and position. It is very important to assist frontline officers in experiencing success and meaningfulness in social service work. The police organization needs to provide professional development opportunities for frontline officers and recognize their efforts at flexibility, adaptability and creativity in their social service work with positive feedback.

\section{Increase Informal Power}

The police administrators are suggested to increase informal power by consciously assisting frontline officers in seeking out opportunities to network and develop positive relationships with superiors and peers. In order to foster an increased understanding of individual officers' roles and overall contribution to the work team, it is necessary to expand frontline officers' knowledge and skills with regard to networking and team building, such as conflict management, planning, and coordination in continuous training provided by professional psychologist and senior police administrators. Hopefully, this may result in more cohesive work teams and greater partnership manifested by trust and respect. In the meanwhile, the police administrators need to provide open, two-way communications with all ranks of officers. This communication approach can promote the sharing of ideas between subordinates and superiors and facilitates effective communication among frontline officers. Internal communications are expected to reach the frontline police officers so as to improve information flow. Also, frontline police officers can increase their informal power by developing positive relationships outside of the police organization through participating in multi-agency cooperation work groups, task forces or committees. Police departments need to collect all possible information and discuss with other governmental departments concerned with social service to share the workload.

\section{Develop Trustworthy Work Relationships}

Trustworthy working relationships within a wide network of alliances are critical to the successful operation of social service work and require increased efforts. Such efforts may include creating a trustoriented support groups within police organizations wherein frontline officers can exchange ideas and feedback on a regular basis with other peers or supervisors. These support groups may lay the foundation for assisting frontline officers in working together.

\section{Develop the Grassroots-Oriented Resources Disposition System}

That means more human resources and equipment need to be put in for handling frontline officer's social service work. Police administrators need to recalculate manpower and equipment based on social service work demands so as to ensure enough manpower and equipment are provided to improve the quality of social service work.

\section{Deliver Information Accurately and Timely}

Delivering the information precisely and timely can build trust and fosters the cooperation between dispatchers of the command center and frontline officers. Access to information can be enhanced through effective written and verbal communication patterns via effective computer aided dispatch (CAD) systems, staff meetings, memos, and newsletters. In addition, police administrators can increase frontline officers' access to information by instituting communication structures that promote superiorsubordinate collaboration. Regular, specific, and timely formal or informal feedback is essential to an effective communication system.

\section{Build Confidence and Achieve Recognition of Social Service Work}

The police organization should be more social service-oriented. In face of the challenging social service work, police administrators need to build confidence among frontline officers. First, police administrators need to understand the nature and scope of frontline officers' social service work and their value of achievement in social service work by listening to what they want to express, and giving them frontline officers their support and appreciation. In this way, frontline officers may feel that they can contribute something to the organizational objectives and that their suggestions are respected and valued. Second, recruitment should emphasize social service-oriented officers. Third, the police organization can offer inservice training and professional development for promoting individual officers sense of competence, and 
create a supportive organizational culture and climate that recognizes, facilitates and encourages social service work. It is necessary to build a positive philosophy in training to connect with the goals and significance of social service work.

\section{LIMITATIONS AND FUTURE DIRECTIONS}

This research is limited by several factors that need to be noted. The findings of this study are based on a comparative small percentage of the total number of police officers employed by the Shenzhen Public Security Bureau (SZPSB). Although this study includes police officers of divergent ranks (from constable, $2^{\text {nd }}$ Class to supervisor, $1^{\text {st }}$ Class), different genders, educational backgrounds and worksites, the comparative small sample size may limit the generalizability of results.

In this study, demographic characteristics (e.g. age, education, and work experience) do not correlate with frontline officers' PSSRS, PSSSE and PSSPE. Further study needs to be done to verify the relationships between personal characteristics and frontline officers' perceptions of PSSRS, PSSSE and PSSPE.

Given that Mandarin is used to conduct the interviews, there are difficulties in completely translating participants' expressions from Chinese to English.

Given that many variables (PSSRS, PSSPE) relate to an individual's subjective perceptions, it is difficult to completely eliminate bias in participant reporting and researcher's analysis and interpretation.

\section{CONCLUSIONS}

Based on theories of role strain (Goode, 1960), structural empowerment (Kanter, 1979; 1993) and psychological empowerment (Spretizer, 1995a; 1995b; 1996; 1997), three key variables central to this study are identified: police social service role strain (PSSRS), police social service structural empowerment (PSSSE) and police social service psychological empowerment (PSSPE). The empowerment, considered as the coping variable, provides an explanatory framework for investigating the roles of PSSSE and PSSPE in alleviating PSSRS. The current organizational structure and styles of management in Chinese policing hinder the delivery of social service. Based on results of the survey and interview, it is likely to establish that the participants are perceiving a high level of PSSRS and low levels of PSSSE and PSSPE. Structural and psychological empowerment can be considered as the coping strategies for police social service role strain. The paramilitary-bureaucratic police organizations limit the effectiveness and efficiency of the Chinese police due to many impersonal rules, the lack of discretion officers are permitted to use, and the hierarchical nature of the organizational structure. The empowerment has the ability to energize performance, produce better solutions to problems, and greatly enhance acceptance of decisions. The current organization structure and management practice of Chinese police force need to be changed, some restructuring of the paramilitary-bureaucratic design is necessary, especially increased trust and confidence between supervisors and frontline officers, increased communication and information flow, more effective decision-making, increased morale, enhanced problem-solving ability, and higher performance and quality of service. The Chinese police should continuously commit to the organizational philosophy and strategy of structural and psychological empowerment to cope with police social service role strain.

\section{ACKNOWLEDGEMENT}

This research is supported by the research grant awarded by the Southwest University of Political Science and Law, China in 2012.

\section{REFERENCES}

Appelbaum, S.H. and Honeggar, K.1998. "Empowerment: A Contrasting Overview of Organizations in General and Nursing in Particular - An Examination of Organizational Factors, Managerial Behaviors, Job design, and Structural Power." Empowerment in Organizations 6(2):29-50. http://dx.doi.org/10.1108/14634449810210715

Baguley, K. 1999. "Workplace Empowerment, Job Strain and Affective Organizational Commitment in Critical Care Nurses: Testing Kanter's Structural Theory of Organizational Behavior." Master's Thesis, University of Western Ontario, London.

Becker, P.E. and Moen, P. 1999. "Scaling Back: Dual-earner Couples' Work-Family Strategies." Journal of Marriage and the Family 61: 995-1007. http://dx.doi.org/10.2307/354019

Biddle, B. J. 1979. Role theory: Expectations, Identities, and Behaviors. New York: Academic Press.

Brown, J. M. and Campbell, E.A. 1990. "Sources of Occupational Stress in the Police." Work and Stress 4: 305-318. http://dx.doi.org/10.1080/02678379008256993

Brown, J. M., and Kanter, R. 1982. "Empowerment: Key to effectiveness." Hospital. Forum 25(3): 6-10.

Conger, J. and Kanungo, R. 1988. "The Empowerment Process: Integrating Theory and Practice." Academy of Management Review 13(3): 471-482.

Cox, S. M. 1996. Police: Practices, Perspectives, Problems. Boston: Allyn and Bacon. 
Cullen, F., Link, B., Wolfe, N., and Frank, J. 1985. "The Social Dimensions of Correctional Officer Stress." Justice Quarterly 2: $505-532$. http://dx.doi.org/10.1080/07418828500088711

Dai, M. Y. 2008. "Policing in the People's Republic of China: A Review of Recent Literature." Crime Law Social Change 50: 211-227.

http://dx.doi.org/10.1007/s10611-008-9131-7

Dempsey, J. S.1999. An Introduction to Policing. Belmont, CA: West/Wadsworth Publishing.

DiTecco, D., Cwitco, G., Arsenault. A, and Andre, M. 1992. "Operator Stress and Monitoring practices." Applied Ergonomics 23: 29-34. http://dx.doi.org/10.1016/0003-6870(92)90007-I

Ford, J.K. 2002. "Organizational Change and Development: Fundamental Principles, Core Dilemmas, and Leadership Challenges in the Move toward A Community Policing Strategy." Pp.126-149 in The Move to Community Policing: Making Change Happen. Edited by M. Morash and J. K. Ford. Sage Publications.

Fu, H. 1990. "Patrol Police: A Recent Development in the People's Republic of China."Police Studies 13(3): 111-117.

Goldstein, H. 1990. Problem-Oriented Policing. New York: McGrawHill.

Goode, W.J.1960. "A Theory of Role Strain." American Sociological Review 25:483-496. http://dx.doi.org/10.2307/2092933

Greene, J. R.and Klocars, C.B.1991. "What Police Do." Pp273-284 in Thinking about Police: Contemporary Readings. Edited by C. Klockars and S. Mastrofski. New York: McGraw-Hill.

Hardy, M. E., and Conway, M. E. 1988. Role theory: Perspectives for Health Professionals. Norwalk, Conn.: Appleton and Lange.

Hickman, M. and Reaves, B. 2001. Local Police Departments, 1999. Washington, DC: U.S. Bureau of Justice Statistics.

Jiang, J., Xu, Y. and Deng, Z. 2005. "The Relationship between Job Strain and Job Stress." Chinese Mental Health Journal 3: 207.

Kanter, R. M. 1979. "Power failure in management circuits." Pp.342351 in Classics of Organization Theory. Edited by J. M. Shafritze, J.S. Ott, and Y.S Jang. Belmont, CA: Wadsworth.

Kanter, R. M. 1993. Men and Women of the Corporation. New York: Basic Books.

Komarovsky, M. 1976. Dilemmas of Masculinity: A Study of College Youth. New York: Norton.

Langworthy, H. R. and Lawerence, Travis III, F. 1994. Policing in America: A Balance of Forces. New York: Macmillan.

Laschinger, H. K. 1996. "A Theoretical Approach to Studying Work Empowerment in Nursing: A Review of Studies Testing Kanter's Theory of Structural Power in Organizations." Nursing Administration Quarterly 20: 25-41. http://dx.doi.org/10.1097/00006216-199602020-00006

Laschinger, H. K., Finegan, J. and Shamian, J. 2001. "The Impact of Workplace Empowerment and Organizational Trust on Staff Nurses' Work Satisfaction and Organizational Commitment." Health Care Management Review 23: 7-23.

http://dx.doi.org/10.1097/00004010-200107000-00002

Laschinger H.K., Finegan J., Shamian J. and Wilk P. 2001. "Impact of Structural and Psychological Empowerment on Job Strain in Nursing Work Settings: Expanding Kanter's Model."Journal of Nursing Administration31 (5):260-272. http://dx.doi.org/10.1097/00005110-200105000-00006

Laschinger, H. K. S. and Havens, D. S.1996. "Staff Nurse Work Empowerment and Perceived Control over Nursing Practice: Conditions for Work Effectiveness." JONA 26(9):27-35. http://dx.doi.org/10.1097/00005110-199609000-00007

Magenau, J. and Hunt, R. 1996. "Police Unions and the Police Role." Human Relations 49(10):1315-1343. http://dx.doi.org/10.1177/001872679604901003
Marks, S. R. 1977. "Multiple Roles and Role Strain: Some Notes on Human Energy, Time and Commitment." American Sociological Review 42(I): 921-936. http://dx.doi.org/10.2307/2094577

Meese, E. 1993. "Community Policing and the Police Officer." Perspectives on Policing15:1-11.

Oliver, W. M. 2004. Community-Oriented Policing: A Systemic Approach to Policing. Upper Saddle River, N.J.: Prentice Hall.

Paden, S. and Buehler, C. 1995. "Coping with the Dual-Income Lifestyle." Journal of Marriage and Family 57(1): 101-110. http://dx.doi.org/10.2307/353819

Palmiotto, M. 1999. Community Policing : A Policing Strategy for the 21st Century. Gaithersburg, Md.: Aspen.

Pareek, U. 1983. "Organizational Role Stress." Pp.115-118 in The 1983 Annual for Facilitators, Trainers, and Consultants, edited by Goodstein, L. D. and Pfeiffer, J.W.. San Diego. University Associates.

Patton, M. Q. 1990. Qualitative Evaluation and Research Methods Newbury Park, CA: Sage.

Paul, P. 2001. "Reading about 'Community (Oriented) Policing' and Police Models." Policing 24(4): 470-496. http://dx.doi.org/10.1108/EUM0000000006496

Peak, K. J., Gaines, L. K. and Glensor, R. W. 2010. Police Supervision and Management: In An Era of Community Policing. Upper Saddle River, N.J.: Prentice Hall.

Pearlin, L.I. and Schooler, C. 1978. The Structure of Coping. Journal of Health and Social Behavior 18:2-21. http://dx.doi.org/10.2307/2136319

Pelfrey, William V. Jr. 1998. "Precipitating Factors of Paradigmatic Shift in Policing: The Origin of the Community Policing Era." Pp 79-92 in Community policing : Contemporary readings, edited by Alpert, G. P. and Piquero, A. R.. Prospect Heights, III.: Waveland Press.

Purpura, P. P. 2001. Police and Community : Concepts and Cases. Boston: Allyn and Bacon.

Reid, S. 2001. Criminal Justice. Cincinnati, OH: Atomic Dog Publishing.

Reiter, M. S. 1999." Empowerment Policing”. FBI Law Enforcement Bulletin 68:7-11.

Ripley, R.E. and Ripley, M.J.1992. "Empowerment, the Cornerstone of Quality: Empowering Management in Innovative Organizations in the 1990's." Management Decision 30(4): 20-43. http://dx.doi.org/10.1108/00251749210014743

Roberg, R. R., and Kuykendall, J. L. 1990. Police Organization and Management: Behavior, Theory, and Processes. Pacific Grove, Calif.: Brooks/Cole.

Roberg, R. R., Novak, K. J., and Cordner, G. W. 2009. Police and Society. New York: Oxford University Press.

Rosenbaum, D. P. 1994. The Challenge of Community Policing: Testing the Promises. Thousand Oaks, Calif.: Sage Publications.

Schmalleger, F., and Worrall, J. L. 2010. Policing Today. Upper Saddle River, N.J.: Pearson/Prentice Hall.

Sina News Center. (March 24, 2005). The Investigation of the Public Security Bureau Reform: Replacing the Name of the Public Security Bureau with Jingchashu. Retrieved March 23, 2010, from http://news.sina.com.cn/c/2005-03-24/15445454563s. shtml.

Spreitzer, G.M. 1995a. "Individual Empowerment in the Workplace: Dimensions, Measurement, and Validation." Academy of Management Journal 38: 1442-1465. http://dx.doi.org/10.2307/256865

Spreitzer, G.M. 1995b. "A Model of Intrapersonal Empowerment in the Workplace." American Journal of Community Psychology 23(5): 601-629. http://dx.doi.org/10.1007/BF02506984 
Spreitzer, G.M. 1996. "Social Structural Levers for Workplace Empowerment." Academy of Management Journal 39(2): 483-504. http://dx.doi.org/10.2307/256789

Spreitzer, G. H. 1997. "Toward a Common Ground in Defining Empowerment." Research in Organizational Change and Development 10: 31-62.

Stevens, D. J. 2003. Applied Community Policing in the 21st Century. Boston: Allyn and Bacon.

Sun, Y. 2007. "An Investigation on Police Job Strain.” Legal System and Society 7: 687.

Thomas, K. and Velthouse, B. 1990. "Cognitive Elements of Empowerment: An 'Interpretive' Model of Intrinsic Task Motivation." Academy of Management Review15: 666-681.

Trojanowicz, R. C., and Bucqueroux, B. 1990. Community Policing : A Contemporary Perspective. Cincinnati, Ohio: Anderson Pub. Co.

Walker, S., and Katz, C. M. 2008. The Police in America : An Introduction. Boston, Mass.: McGraw Hill.

Wall, T.D., Cordery, J.L. and Clegg, C.W. 2002. "Empowerment, Performance and Operational Uncertainty: A Theoretical Integration." Applied Psychology: An International Review 51:146-169. http://dx.doi.org/10.1111/1464-0597.00083

Wang, X.H. and Wong, S.W..2012. "Police Social Service Work in China: Community Policing with Chinese Characteristics." Asia Pacific Journal of Police and Criminal Justice 9(1): 3454.
Winegar, S. 2003. Motivation in the Workplace: An examination of psychological empowerment of Police Officers in Oregon. Unpublished Dissertation, PSU, Portland. C. Tracy.

Wong, K. C. 2001. "Community Policing in China: Philosophy, Law and Practice." International Journal of the Sociology and Law 29(2): 127-147. http://dx.doi.org/10.1006/ijsl.2001.0146

Wong, K.C. 2002. "Policing in the People's Republic of China: The Road to Reform in the 1990s." The British Journal of Criminology 42 (2): 282-316. http://dx.doi.org/10.1093/bjc/42.2.281

Wong, K. C. 2009. Chinese Policing : History and Reform. New York: Peter Lang.

Wuestewald, T. and Steinheider, B. 2006. "Shared Leadership: Can Empowerment Work in Police Organizations?." The Police Chief 73: 48-55.

Xia, X. and Guo, J. 2002. Historical Development and Characteristics of Social Work in Today's China. International Social Welfare 11:254-262. http://dx.doi.org/10.1111/1468-2397.00222

Zhong, Lena. Y. 2009. "Community Policing in China: Old Wine in New Bottles." Police Practice and Research 10 (2):157-169. http://dx.doi.org/10.1080/15614260802264594

Zhou, X.J. 2005. "The research on Police Job Strain and Coping." Policing Studies 2:67-71.

\section{DOI: http://dx.doi.org/10.6000/1929-4409.2014.03.03}

(C) 2014 Xiaohai Wang; Licensee Lifescience Global.

This is an open access article licensed under the terms of the Creative Commons Attribution Non-Commercial License (http://creativecommons.org/licenses/by-nc/3.0/) which permits unrestricted, non-commercial use, distribution and reproduction in any medium, provided the work is properly cited. 